\title{
FÉ E DIVERSÃO: DEVOÇÃO À ROSÁRIO DOS PRETOS E OUTRAS MANIFESTAÇÕES CULTURAIS EM UMA COMUNIDADE QUILOMBOLA ${ }^{1}$
}

\author{
Cledineia Carvalho dos Santos ${ }^{2}$ \\ Fernando Conceição ${ }^{3}$
}

DOI 10.26512/revistacalundu.v4i1.30564

\begin{abstract}
Resumo
A partir de uma análise histórico-cultural o presente texto aborda a relação entre cultura, identidade, fé, diversão e as subjetividades tecidas no imaginário social entre os sujeitos que compõem a comunidade quilombola Nova Esperança. A partir dessa, buscamos discutir as diversas manifestações religiosas e culturais quilombola. A comunidade, para além da diversão, realimenta sua fé e fortalece os laços de identidade. Nas festividades, a comunidade mistura o sagrado e o profano sem que com isto maculem sua fé, sendo na verdade aspectos indissociáveis. No âmbito da cultura, a religião neste espaço se manifesta em formas simbólicas da relação com os outros e permeia a vida cotidiana.
\end{abstract}

Palavras-chave: Cultura. Religião. Diversão. Comunidade Quilombola.

\section{FÉ Y DIVERSIÓN: DEVOCIÓN A ROSARIO DE LOS PRETOS Y OTRAS MANIFESTACIONES CULTURALES EN UNA COMUNIDAD QUILOMBOLA}

\section{Resumen}

Basado en un análisis histórico-cultural, este texto aborda la relación entre cultura, identidad, fe, diversión y las subjetividades entretejidas en el imaginario social entre los

\footnotetext{
${ }^{1}$ Este trabalho é uma versão ligeiramente modificada de um tópico do segundo capítulo da dissertação de mestrado em Cultura e Sociedade " Comunidade quilombola Nova Esperança: a mulher na construção da identidade étnica ", defendida na Universidade Federal da Bahia/UFBA.

${ }^{2}$ Mestra em Cultura e Sociedade pela UFBA (2018); Especialização em Língua Portuguesa pela UESB (2011); Especialização em Língua Portuguesa e Literatura Brasileira pela Faculdade Vale do Cricaré (2012); Especialização em História (em andamento) pela UNIVES; Licenciada em Letras pela UESB Universidade Estadual do Sudoeste da Bahia - Campus de Jequié (2009), Licenciatura em História pela UNEB - Universidade do Estado da Bahia - Campus XXI - Ipiaú (2014). Coordenadora Pedagógica na Escola Paulo Freire (Jaguaquara/Ba). keucarvalho@yahoo.com.br

${ }^{3}$ Professor Titular da Universidade Federal da Bahia. Docente e pesquisador do Poscultura - Programa Multidisciplinar em Cultura e Sociedade, ligado ao IHAC - Instituto de Humanidades, Artes e Ciências Milton Santos e da Faculdade de Comunicação. Tem estágio-sênior pós-doutoral no CES - Centro de Estudos Sociais/Laboratórios Associados/Universidade de Coimbra, Portugal e Pós-Doutorado na Freie Universität Berlin/Lateinamerika-Institut. É biógrafo autorizado do intelectual e geógrafo Milton Santos, vencedor do "Nobel" da Geografia (Prêmio Vautrin Lud). Doutor e Mestre em Ciências da Comunicação na Universidade de São Paulo, possui graduação em Comunicação/Jornalismo pela Universidade Federal da Bahia. No Poscultura coordena os grupos de pesquisa Permanecer Milton Santos; e Etnomidia - Grupo de Estudos em Mídia e Etnicidades da UFBA. fernconc@ufba.br
} 
sujetos que componen la comunidad quilombo Nova Esperança, en la cual buscamos discutir las diversas manifestaciones religiosas y culturales quilombola. La comunidad, además de divertirse, refuerza su fe y fortalece sus lazos de identidad. En las festividades, la comunidad mezcla lo sagrado y lo profano sin dañar su fe, siendo, de hecho, inseparable. En el contexto de la cultura, la religión en este espacio se manifiesta en formas simbólicas de la relación con los demás e impregna la vida cotidiana.

Palabras clave: Cultura. Religión. Divertido. Comunidad Quilombola.

Bendita e Louvado seja!

Ó virgem, Mãe verdadeira!

Proteja Nova Esperança, nossa Excelsa padroeira! Proteja Nova Esperança, nossa excelsa padroeira!

Ô virgem Mãe do Rosáriol

Vos peço como lembrança.

Peço a vós que não esqueçal do Povo de Nova Esperança. Peço a vós que não esqueçal do Povo de Nova Esperança.

(Trecho do Hino à Nossa Senhora do Rosário por Senhorinha dos Santos, moradora da Comunidade Nova Esperança, 1980).

\section{Entre Fé e a Devoção: a Cultura, o Sagrado e o Profano. Breves definições}

A cultura é o que nos torna o que somos a partir do lugar onde vivemos. Nela elaboramos um universo simbólico de nós na relação com os outros com os quais compartilhamos valores e crenças. Nesse sentido, a cultura deve ser entendida como uma complexa rede de relações sociais e identitárias.

Perante esta concepção, Cuche (2002, p. 39 apud LARAIA 2006, p.25) diz que a “cultura é este todo complexo que inclui conhecimentos, crenças, arte, moral, leis, costumes ou qualquer outra capacidade ou hábitos adquiridos pelo homem como membro de uma sociedade".

Assim sendo, ao discutirmos como a comunidade entrelaça suas relações entre fé e festas; sagrado e profano; diversão e devoção, se faz necessário pensar a cultura no plural, conforme discute Franz Boas (2004), para o qual cada grupo tem sua história própria e única, devendo ser avaliada dentro seus próprios termos, que integram a vida coletiva.

Em se tratando dos aspectos culturais, as comunidades quilombolas se configuram como uma fonte de riqueza do Brasil. Segundo a Fundação Cultural Palmares (BRASIL, 2003, art. $2^{\circ}$ ) "são espaços de preservação da história e onde se 
projetam a identidade étnica e a solidariedade mútua, valores já não tão observados na grande sociedade". Por ser uma manifestação essencialmente humana, as pessoas de comunidades quilombolas festejam seu imaginário social, onde o sagrado e o profano se confundem.

Assim como a cultura é inerente à própria ação humana, a identidade também é construída na coletividade valendo-se das crenças, da memória, das fantasias, das relações de poder e das práticas religiosas. Conforme afirma Hall (2008, p. 109), "as identidades são construídas dentro e não fora do discurso", sendo dialógico. Perante esta concepção é que discutimos o sagrado e o profano. Um só existe em contraponto ao outro.

O sagrado, aquilo que é 'colocado à parte', é definido e marcado como diferente em relação ao profano. $\mathrm{Na}$ verdade, o sagrado está em oposição ao profano, excluindo-o inteiramente. As formas pelas quais a cultura estabelece fronteiras e distingue a diferença são cruciais para compreender as identidades. A diferença é aquilo que separa uma identidade da outra, estabelecendo distinções, frequentemente na forma de oposições [...] (WOODWARD, 2000, p. 41).

Como o próprio excerto indica, o profano é definido como tudo aquilo que está em contraponto ao sagrado. Profano é tudo que não é sagrado, toda a vida comum do dia a dia, os fatos e atos da rotina. É o que envolve os atos exclusivamente dos desejos carnais, que a princípio não são aceitos no âmbito do sagrado. É o extravasar de tudo aquilo que o sagrado condena. No entanto, esses dois fatores perpassam por fronteiras identitárias que, a depender dos interesses, são readequadas para atender a coletividade.

Portanto, o profano e o sagrado só acontecem na experiência individual e dos grupos, e os próprios grupos são quem definem o que é profano ou sagrado, dependendo de suas experiências religiosas.

É nesta perspectiva que a as manifestações religiosas de Nova Esperança se estabelecem. Para a comunidade, os acontecimentos que ocorrem fora do âmbito do sagrado não interferem na fé que professam aos seus santos. Ao contrário, uma abastece os outros como forma de sobrevivência.

A fé enquanto dimensão antropológica é parte da própria existência humana, independente de sua matriz religiosa. A fé está intrínseca entre os sujeitos, em todos os lugares e tempos. É essa fé que norteia cada agrupamento humano ou sujeito ao longo de sua jornada distinguindo o que é importante para cada um. 
É perante a fé que, ao realizar os festejos aos santos e folguedos da comunidade, os sujeitos de Nova Esperança estruturam seus valores e seus ideais de comunidade. Cujo objetivo é a busca pelo sagrado através de ofertas, rezas e oferendas aos santos de devoção.

Nestes termos, a fé é:

A transmissão de dados transcendentes, decisivos para o mundo de valores, e a adesão a uma tradição de testemunhas referenciais de aquisição e experiências desses dados. Somente quando estes dois elementos estão presentes, falaremos com certa precisão - de "fé religiosa" (SEGUNDO, 1985, p. 103-104).

Salienta-se que a fé no bojo desta discussão não pode ser definida apenas pelo ato religioso, mas no seu sentido antropológico, instituídas no interior das ações entre os sujeitos que buscam cada um a seu modo, a unidade da comunidade.

Por isso, a fé também se entrelaça com a diversão, sendo esta mais atrelada ao profano. Divertir durante os festejos é inerente às práticas que persistem após as obrigações e devoções aos santos e folguedos.

As culturas populares representadas nas festas da comunidade a tornam singular, pelo fato de serem justapostas. Não há fé sem a diversão. Os atos de devoção aos santos da comunidade têm, nos seus festejos, práticas simbolizadas nas comidas, no artesanato, na música, na dança, celebrações, no samba de roda, forró e outras manifestações culturais.

Em Nova Esperança se festeja a vida a partir da devoção aos santos da comunidade, os dias santos como o Natal, Dia de Reis, a Páscoa e o São Pedro, e as festas individuais como o Caruru ${ }^{4}$ de São Cosme e São Damião. É nas festas que os remanescentes desse território reelaboram suas memórias, quebram a rotina,

\footnotetext{
${ }^{4} \mathrm{O}$ caruru é uma comida típica da culinária baiana e muito utilizada pelos adeptos do Candomblé. Embora haja divergências quanto a sua origem - que também possui influências da cultura indígena, representada por um tipo de planta que, inclusive, leva esse nome -, provavelmente foi trazido e adaptado no Brasil pelos africanos. Esses deram uma simbolização muito particular ao caruru, além de acrescentar outros ingredientes e valores que hoje se tornaram uma referência desse prato. O seu preparo é acompanhado dos seguintes ingredientes: quiabo cortado miúdo e cozido em caldo de peixe seco e temperado com sal, alho, cebola ralada, camarão seco e batido no pano, pimenta ralada quioiô, castanha assada e moída, catassol torrado e azeite de dendê. Os quiabos devem ser cortados em cruz no sentido longitudinal e depois, então, em rodinhas bem finas. Esse cuidado possui um cuidado mitológico, pois simboliza as origens e a história das ancestralidades africanas, representadas particularmente em cada prato típico. Também é importante o uso de utensílios rústicos, como panela de barro, gamela e colher de pau, peneira, entre outros, para preservar a originalidade de uma tradição que remota o passado. Embora o caruru seja consumido no Brasil durante a semana santa, é no dia 27 de setembro que ele assume sua maior importância. Nesse dia, os devotos sincretizam Cosme e Damião nos orixás africanos, pagam promessas e oferecem o caruru para sete meninos. (SANTANA, 2014).
} 
confraternizam com os reencontros familiares e realimentam sua fé. São também as manifestações culturais a oportunidade da "subversão" aos paradigmas cotidianos. Lá, comemora-se o existir. Para Eliade,

toda festa religiosa, todo Tempo litúrgico, representa a reatualização de um evento sagrado que teve lugar num passado mítico, nos "primórdios". Participar religiosamente de uma festa implica a saída da duração temporal "ordinária" e a reintegração no Tempo mítico reatualizado pela própria festa (ELIADE, 2008, pp. 63-64).

Com isto, a comunidade busca através de suas manifestações, resistir no tempo e lugar enquanto testemunho vivo da resistência à escravidão, pois no período escravocrata "os escravizados aproveitavam as celebrações do calendário cultural dos senhores para praticarem suas próprias tradições culturais, entre as quais a tradição, frequentemente reinventada, de se organizarem segundo a origem étnica” (Reis, 1996, p. 03).

Nesse sentido, as origens das festas estão intimamente ligadas a eventos sagrados, econômicos e políticos do lugar. Sendo constantemente reinventado e atualizado, como argumenta Roy Wagner: "em certo sentido, a invenção não é absolutamente um processo inventivo, mas um processo de obviação" (WAGNER, 2010, p.240).

\section{A Comunidade Quilombola Nova Esperança}

O território do qual trata o presente estudo é um lugar de remanescentes quilombolas $^{5}$, localizado no município de Wenceslau Guimarães ${ }^{6}$, Território de identidade do Baixo-Sul da Bahia ${ }^{7}$, distante 290 km de Salvador. Conforme o censo $2010^{8}$ a população de Wenceslau Guimarães é de 22.189 habitantes.

A respeito da fundação da comunidade, segundo narrativas dos moradores mais velhos da comunidade, se dá pela chegada de seu fundador, o Sr. Faustino dos

\footnotetext{
${ }^{5} \mathrm{O}$ conceito de quilombo utilizado é aquele previsto no artigo $6^{\circ}$ do Ato das Disposições Constitucionais Transitórias da Constituição Federal de 1988, sob o enunciado: “Aos remanescentes das comunidades de quilombos que estejam ocupando suas terras reconhecida a propriedade definitiva, devendo o Estado emitir-lhes os títulos respectivos."

6 Emancipada em 1962, Wenceslau Guimarães é um município brasileiro do estado da Bahia. Sua população estimada em 2013 era de 23.046 habitantes. É o maior produtor nacional de graviola e bananada-terra. De acordo os dados do IBGE o munícipio tem uma área de 655,239 km2 e com população estimada em 22.445 habitantes conforme dados de 2016.

${ }^{7}$ Ver mapa - imagem 03/ Apêndices

${ }^{8}$ Disponível em: http://populacao.net.br/populacao-wenceslau-guimaraes_ba.html
} 
Santos, e sua família, por volta da primeira metade do século $\mathrm{XX}$, mais precisamente em 1929.

Oriundos do Sertão da Bahia, fugiram da Guerra de Canudos e da seca que devastou a região, a pé, carregando seus pertences em surracas ${ }^{9}$ e algumas economias em dinheiro, adquirido através do trabalho realizado de fazenda em fazenda. Após meses de viagem, ele e sua família chegaram à região onde hoje situa-se Nova Esperança. Neste advento, encontraram alguns posseiros ${ }^{10}$, entre eles Manoel Calixto, com quem o patriarca adquiriu as terras onde atualmente fica a comunidade apresentada.

$\mathrm{Na}$ época, a comunidade era pertencente ao município de Nilo Peçanha Bahia (Getúlio dos Santos, entrevista, 2016). Assim, em 1929, o senhor Faustino José dos Santos fundou a comunidade Nova Esperança pensando, utopicamente, em um futuro melhor para sua família. E como tal, a comunidade é um lugar de novas esperanças para a sua gente; gente que nunca esqueceu o seu passado e de onde veio, que luta pela efetivação dos seus direitos mais fundamentais que lhes foram historicamente negligenciados, como, o direito definitivo da terra, o reconhecimento da cidadania, a preservação de seu patrimônio cultural e a reversão de estigmas racistas.

O povoado de Nova Esperança é composto por 95 famílias, totalizando 387 pessoas. Quanto à distribuição por gênero existe aproximadamente $44 \%$ de homens e $56 \%$ de mulheres ${ }^{11}$. Os quilombolas vivem da lavoura do cacau, da banana e da graviola, todas produzidas em escala comercial. Paralelo a estas culturas, têm ainda produções de subsistências, como o milho, a mandioca, laranja, feijão e criação de animais de pequeno porte para consumo próprio.

A relação de trabalho acontece entre os proprietários das terras e os prestadores de serviços, os chamados diaristas. Esporadicamente, há trocas de serviços, conhecido como "d'mão ${ }^{12}$ ". Outra relação muito comum é a de meeiros, que consiste na troca de serviços entre o dono das terras e ou plantações e o lavrador. Neste tipo de trabalho, ocorre a divisão igual dos lucros. A convivência estabelece-se a partir de laços de parentescos e de compadrio, isto colabora para

\footnotetext{
${ }^{9}$ Saco onde os sertanejos colocavam seus pertences e carregavam sobre as costas.

${ }^{10} \mathrm{O}$ termo posseiro é aqui utilizado pelos colaboradores como sinônimo de primeiros ocupadores das terras da região.

${ }^{11}$ Dados colhidos na Associação de moradores.

${ }^{12}$ D' mão refere-se ao trabalho coletivo, tipo mutirão.
} 
uma convivência pacífica entre os moradores. Outro fator preponderante é a luta pelo reconhecimento da comunidade enquanto lugar de ancestralidade negra.

A comunidade de Nova Esperança mantém atributos obtidos desde sua fundação. Lugar de pessoas simples que buscam manter suas tradições para a manutenção da sua identidade, demonstrada nas organizações dos eventos comunitários, nas atividades agrícolas, na escolha de seus representantes políticos, enfim, pelos interesses nos objetivos comuns, através da Associação de Moradores, instituição que viabiliza a busca pelos direitos da comunidade, a exemplo da "merenda escolar diferenciada" e do escoamento de parte dos produtos agrícolas, como o cacau, a graviola e a banana.

Por certo, ser quilombola para os moradores dessa comunidade perpassa por um longo processo de compreensão de seu passado histórico e de reconhecimento de si enquanto remanescentes.

\section{A fé, a devoção e as festas em Nova Esperança}

Nova Esperança é composta de um povo alegre, festeiro, também de fé. Nesse construto, a mulher não tem apenas a função da liderança política, material e do trabalho, a elas implicam também, a manutenção cultural, religiosa e espiritual. São elas as responsáveis para organizar as festas da igreja, o Terno de Reis, os festejos juninos, desde a programação às comidas.

O catolicismo, religião predominante, está presente desde a época da fundação da comunidade por causa das devoções de Antônia Maria e Faustino dos Santos, os fundadores da comunidade. As festas à Santo Antônio (Mês de Junho) e para Nossa Senhora do Rosário (realizada em outubro) são dois grandes momentos da religiosidade local.

No que se refere aos festejos a Nossa Senhora do Rosário, padroeira da comunidade, ocorre na última semana de outubro. A mesma é marcada pela devoção da maioria dos moradores que durante os dias de festa se agrupam na capela para louvar e adorar a Santa. 
Figura 01: Quadro de Nossa Senhora do Rosário

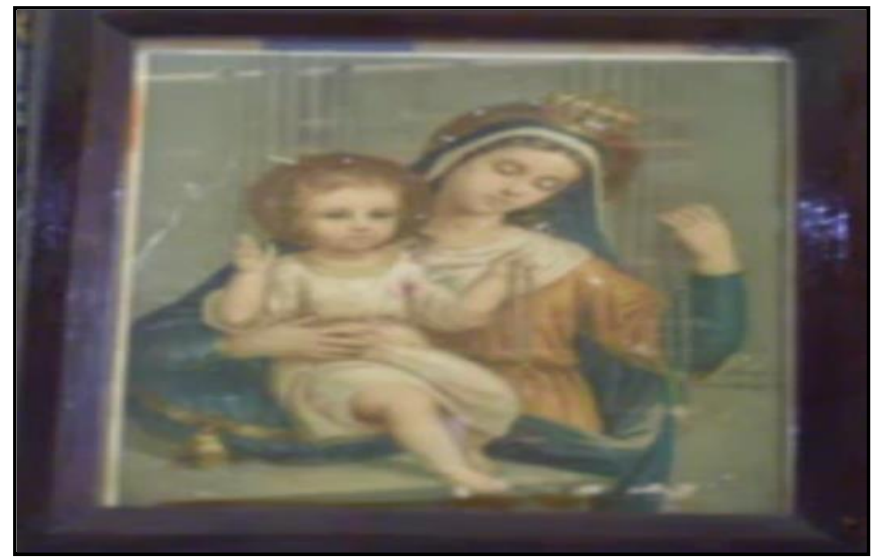

Fonte: acervo da comunidade

Nossa Senhora do Rosário tem importante representação para a identidade local, posto que sua chegada se dá junto ao surgimento da comunidade. A imagem (figura1) está na comunidade desde a sua fundação. Segundo relatos dos moradores mais antigos e herdeiros do fundador, a santa foi trazida por Faustino dos Santos, conforme relata Getúlio dos Santos (2016):

Tinha festa na casa do meu avô todo sábado, ele rezava, era devoto nos termos a igreja hoje. A padroeira é a Nossa Senhora do Rosário, essa Nossa Senhora do Rosário (Imagem que se encontra na igreja) acompanhou ele. Eu sei que ele trouxe de lá de Sururu de Queiroz trouxe pra Lagoa do Morro e veio pra aqui e ela ta na igreja, apareceu uma Santa Nova, as meninas eu digo, olha se vê que vai jogar essa no mato me dá que eu levo lá pra casa (risos)! Aí agora tomaram zelo. Elas ciúmam, aí nós temos a devoção de Nossa Senhora do Rosário, tem a festa dela (Getúlio dos Santos, entrevista, 2016).

Em consonância, Florinda dos Santos diz: "Eu lembro que Ele (Faustino dos Santos) contava que Nossa Senhora do Rosário, era a Santa de devoção do pai dele porque era a padroeira dos negros (...). Ele dizia assim: Nossa Senhora do Rosário é a padroeira dos pretos! É a padroeira dos pretos!” (Florinda dos Santos, entrevista, 2017).

Apesar de as religiões de matrizes africanas resistirem ao processo opressor aos quais foram submetidos, o catolicismo já havia se consagrado na memória coletiva do povo brasileiro, pois oa mesma já existia no país antes da chegada dos africanos. Assim, a devoção da comunidade à Nossa Senhora do Rosário, tem uma relação histórica com o passado do povo negro no Brasil, como salienta João José Reis (1996) 
Antes mesmo que o primeiro escravo desembarcado no Brasil se rebelasse, os senhores e autoridades coloniais já sabiam ser necessário controlar seu corpo e seu espírito. O regime escravocrata, como todo regime de trabalho forçado, baseou-se fundamentalmente no chicote e em outras formas de coerção, mas não teria vigorado por muito tempo se só usasse a violência. Desde cedo os escravocratas aprenderam que era preciso combinar a força com a persuasão, assim como os escravizados aprenderam ser impossível sobreviver apenas da acomodação ou da revolta (REIS,1996. p.03).

Este fato contribuiu para a catequização dos africanos que aqui aportaram como escravizados. Um dos motivos para a aceitação do catolicismo foram os pontos em comum, como a subordinação ao um ser superior (no catolicismo é Deus) e a condenação ao suicídio, prática comum entre alguns povos como forma de resistência a opressão escravagista. Para Alves (2008, p. 94 apud QUINTÃO, 2002), os bantos foram os que mais se adaptaram ao catolicismo representado pelas irmandades.

A crença de que os santos eram os intercessores entre os homens e Deus colaborou para a devoção aos santos católicos por parte dos negros. Mas as irmandades (dos brancos) não aceitavam a participação dos pretos em seus cultos. Em resposta, os negros criaram suas próprias irmandades (irmandades dos pretos) cujo intuito, era a cultuação aos seus santos e também como confraria política, nos quais organizam os sepultamentos e busca por compra de alforrias de seus entes queridos.

Em síntese, o louvor para os santos negros configura-se como sendo uma recriação da África no Brasil ao se perceberem sem "saída" para o catolicismo imposto. Ou melhor, uma estratégia para fugir da chibata. Assim, Nossa Senhora do Rosário e outros santos negros foram substituindo os Orixás africanos. E os quilombolas se apegaram a Nossa Senhora do Rosário. Essa santa, provavelmente, foi escolhida pelo simbolismo da maternidade, misticismo presente nas religiões africanas.

Com isso, a devoção para Rosário dos pretos se afirmou, especialmente entre o povo negro, sendo levada para onde estes fossem, e se perdura na contemporaneidade. Principalmente nas comunidades negras que de alguma maneira tem sua história ligada a escravidão e a resistência, como descreve a moradora de Nova Esperança.

Descobrimos no ano passado, quando escrevemos uma história de várias comunidades que tem como padroeira dos negros, descobrimos que todas elas são quilombolas. A primeira está em Salvador. Hoje nós reconhecemos que ela é padroeira dos negros e a gente não sabia o porquê. Mas hoje a gente entende. Nós somos quilombolas, povo que sofreu (Senhorinha dos Santos, entrevista, 2017). 
Os devotos louvam outros Santos, mas Nossa Senhora do Rosário é a mãe, merecendo toda honra e grande festejo, pois para a moradora "Nossa Senhora do Rosário é a nossa devoção. Além da fé, a gente tem que ter respeito a Nossa Senhora, por isso (por ser a padroeira dos pretos!)" (Florinda dos Santos, entrevista, 2017).

A festa acontece no mês de outubro, com intensa participação da comunidade. São 11 dias de festa desde os tempos da fundação da comunidade, onde primeiro acontece na igreja a reza do terço, missa e louvores. Depois, já no espaço livre as pessoas aproveitam para conversar, comer, participar de sorteios, etc. A mesma é organizada pelas mulheres que se mobilizam de forma intensa para arrecadação de doações para a realização, como anuncia a devota Senhorinha dos Santos: "a gente ajuda. Faz parte de toda celebração da missa" (Senhorinha dos Santos, entrevista, 2017).

Em Nova Esperança, a festa da padroeira local é uma oportunidade de regeneração no tempo presente de um passado que ainda persiste na memória, sempre imbuídos para um novo tempo de viver humanamente, historicamente e sociologicamente. Ou seja, a religião é para o povo negro explicação para além da existência.

Apesar da religião protestante ${ }^{13}$ começar a se difundir entre os membros da comunidade, possuindo muitos adeptos, o catolicismo ainda é muito presente, visto que, entre outras manifestações, destaca-se a celebração da Semana Santa, momento que vivem os mistérios dolorosos de Jesus Cristo.

Nestes dias, as imagens dos santos são cobertas por panos, como manda a tradição local. Eles jejuam e se reúnem na igreja para rezar em respeito à morte de Cristo. Na sexta-feira dessa semana, porém, há muita fartura nas mesas e o cardápio principal é o peixe e o caruru de taioba. Já no sábado, comemoram o "Aleluia", a ressureição de Cristo. Tem moradores que guardam especialmente este dia por "ser o verdadeiro dia de devoção, porque foi o dia que Nosso Senhor Jesus cristo ressuscitou. Então a gente guarda sem comer carne vermelha. Veio de nossos avós e a gente preserva até hoje". (Otavio dos Santos, entrevista, 2017).

Além da festa da padroeira, a comunidade celebra também a festa para Santo Antônio, santo de devoção da matriarca Antônia Maria de Jesus. Quando em vida, todos os anos, no mês de junho acontecia a trezena de Santo Antônio na sua casa onde se

\footnotetext{
${ }^{13}$ São todas as representações do cristianismo fora do catolicismo. "Então, protestantes seriam aquelas igrejas que se originaram da Reforma que, embora surgidas posteriormente, guardam os princípios gerais do movimento. Essas igrejas compõem a grande família da Reforma: luteranas, presbiterianas, metodistas, congregacionais e batistas". (MENDONÇA, 2005).
} 
terminava com uma grande festa em homenagem ao santo. Com o passar dos anos os festejos passaram a acontecer na capela da comunidade. Santo Antônio se configura para os descendentes da fundadora como um mito de fé que os movem, pois Antônia Maria era muita religiosa e deixou esse legado para os seus.

A celebração à Santo Antônio, portanto, faz brotar e rebrotar memórias em conjunção entre passado e presente, "Dindinha Antônia era muito reservada. Se cobria toda para rezar. Todo domingo sentava na frente do rádio para escutar e seguir a missa. Andava toda coberta. Ainda hoje nós queremos seguir o seu jeito. Fazer tudo como ela gostava" rememora (Florinda dos Santos, entrevista, 2017).

O festejo para o santo antecede outro momento importante para os moradores: a festa de São Pedro. A proximidade de realização entre os dois folguedos contribui para uma íntima relação entre o sagrado e profano, pois em clima de festa, todos os dias depois da reza na igreja, os moradores se reúnem em uma grande cabana de palha que eles constroem para dançar ao som do forró e do arrocha ${ }^{14}$.

Sobre a fusão entre o profano e o sagrado, argumenta Passos:

No contato com as tradições populares, o catolicismo foi-se transformando e assumindo os códigos, as metáforas e a linguagem popular. Dor, alegria, esperança, anseios e festas foram compondo o dia-a-dia das expressões religiosas populares. Numa explosão de vozes e ritmos, a devoção popular acompanha o povo no itinerário da vida. Os sinais festivos espalham, enchem capelas e ruas (PASSOS, 2011, p. 03).

Importante dizer que há uma intensa participação dos idosos na festa. Tanto é que bancos são montados dentro do espaço afim de acomodá-los. Os mesmos dançam, brincam, bebem numa relação cordial entre gerações.

Este encontro entre gerações serve como remodelagem dos espaços e das relações em momentos de comunhão para o qual a história local é recriada pela oralidade, resistindo ao tempo. Os mais velhos primam pela tradição, os mais jovens celebram os reencontros e colaboram para o permanecer. Há um emaranhado de relações profundas de celebração com as reminiscências do passado já que "nossas lembranças permanecem coletivas e nos são lembradas por outros, ainda que se trate de eventos em que somente nós estivemos envolvidos e objetos que somente nós vimos" (HALBWACHS, 1990, p. 30).

14 É um gênero musical e dança brasileira originário da cidade de Candeias, na Bahia. Ele veio proveniente da seresta, influenciado pela música romântica e o estilo romântico, com modificações que o tornaram, segundo seus adeptos, mais sensuais e eufóricos com influencias do axé e do forró. 
A religiosidade é uma das características marcantes da comunidade. A Festa de Reis, representa a hibridização cultural absorvida pelo povo negro, caracterizada pela relação entre festas e celebração religiosa, reinventada no catolicismo popular e apontada por Hall como "poderosa fonte criativa, produzindo novas formas de culturas, mais apropriada à modernidade tardia que às velhas e contestadas identidades do passado" (Hall, 2005, p.91)

O Terno de Nova Esperança é composto de ritos, dogmas e cerimônias em torno dos festejos em homenagem aos reis Magos e apresenta-se como símbolo de resistência da cultura e oralidade de um povo que mantém nos seus lábios toda uma sabedoria, toda uma vivência, e todo um amor pela religiosidade, que é cantada por crianças, jovens e idosos todos os anos no mês de janeiro, quando os presépios natalinos são desmontados e a comunidade vai agradecer.

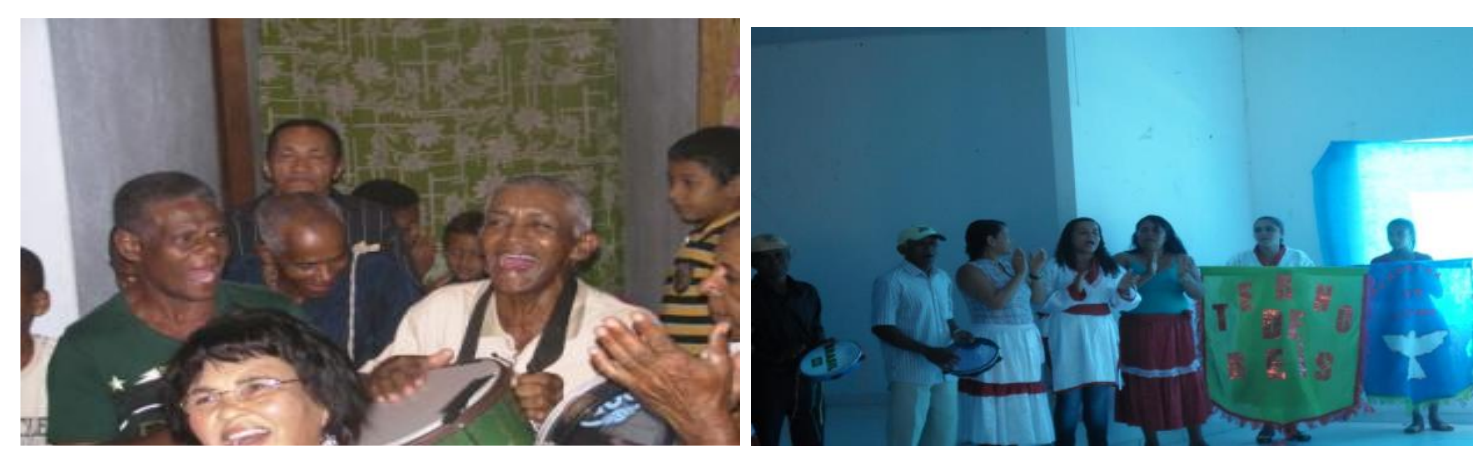

Figuras 02 e 03: Imagens da Festa de Reis

Fonte: acervo da comunidade

As imagens (02 e 03) são amostragens de momentos distintos da festa de Reis. Na primeira a visitação das casas e o samba, bastante sugestiva ao que tange a diversão no decorrer dos acontecimentos. Na segunda, o momento anterior a visitação. É o momento reservado a fé e a devoção aos Santos Reis, realizado na igreja local.

Com isso observa-se a relação íntima entre os rituais católicos e o sincretismo religioso, pois a festa dá continuidade com as visitações de casa em casa e aquela que "aceita" a chegada do terno festeja com bebidas e guloseimas típicas do lugar.

O terno de Reis de Nova Esperança surge concomitantemente com a chegada do desbravador do lugar, o Sr. Faustino, que apesar de muito religioso, gostava de festa. Então, o Terno de Reis passou a ser a extensão dos ritos religiosos no intuito de entreter 
os foliões por mais tempo na festa, até o raiar do dia, e que permanece até os dias atuais. Esse festejo presente na comunidade, têm "ênfase nas origens, nas continuidades, na tradição e nas intemporalidades...” (HALL, 2005, p. 32).

Os integrantes do terno saem em visitação com suas indumentárias e tocando instrumentos artesanais, como tambores, pandeiros e sanfonas, que seguido por todos vão até as casas com o Presépio onde pedem licença para entrar. $\mathrm{O}$ dono da casa permanece com as portas da casa fechada só abrindo após os sambadores cantarem entre duas e três cantigas. Quando a casa abre as portas, acontece a representação da alegria com muitas comidas e bebidas típicas seguida de muitos sambas. É possível perceber esta mistura no relato de um morador

O Terno de Reis prá nós é uma apresentação da religião herdada de nosso avô. Todo ano depois das festa ... a missa , sempre terminava com o Terno de Reis. Hoje os "jove" não quer participar. Diz ser coisa de velho. Eu gosto muito. Gosto de festa. Sempre gostei de dançar. To nessa idade e todo ano to aqui. Hoje ficou uma coisa importante para o lugar. Depois que aqui virou quilombola (Getúlio dos Santos, entrevista, 2016).

Nota-se na fala do colaborador, o sentimento de perda de entusiasmo dos jovens para dar seguimento à cultura herdada de seus ancestrais. Esta preocupação tem certa razão de ser, posto que são poucos os jovens que mostram interesse em pegar os instrumentos ou "puxar" um samba; outro possível fator é a saída destes para a cidade grande em busca de melhores condições de trabalho e educação.

O terno é composto por parentes, amigos, geralmente pelas pessoas mais velhas, mas não impede ninguém que queira participar de integrar-se ao grupo. As indumentárias idealizam a visão do sagrado com a bandeira que representa a Trindade e atualmente outro estandarte foi incluso no conjunto, a bandeira do "Quilombo", o que representa a afirmação da identidade e que Wagner (2010) vai chamar de Cultura inventiva ao argumentar:

[a cultura] opera através de nossos formulários, cria em nossos termos, pede emprestado nossas palavras e conceitos para seus significados e nos recria através dos nossos esforços. (...) Se a nossa cultura é criativo, então as "culturas" estudamos, como exemplos desse fenômeno dos outros, também deve ser. Para cada vez que fazemos os outros parte de uma "realidade" que só nós inventamos, negando a sua criatividade (WAGNER, 2010, p. 16 ).

Em consonância ao exposto, a cultura é inventiva porque é transversal aos 
diversos campos da vida cotidiana, sendo móvel. Cada sujeito ou coletivo a define. A cultura é viva, é inventiva, é identitária e, tantos outros leques mais.

Esta concepção multidisciplinar de cultura aplica-se a diversidade de acontecimentos que envolve as festividades religiosas da Comunidade Quilombola Nova Esperança, pois em cada folguedo adequam-se a realidade do momento, a fim de que seja garantida a realização do evento, seja por questões políticas locais, seja por causas dos fenômenos da natureza, ou por o infortúnio de um luto. O que não pode é o evento deixar de acontecer.

Assim, a cultura opera como modos de vida que caracterizam uma coletividade. Nisto, a concepção de cultura cravada por Fraz Boas (2004) tem todo sentido.

As indumentárias também têm significados no qual cada cor tem uma representatividade, seja no campo do sagrado ou da cultura local. As roupas, as comidas colaboram para a afirmação da identidade quilombola que reproduzem acrescendo significados de acordo com o que desejam que o outro veja e saiba da comunidade, no intuito de se manter frente às novas perspectivas de políticas culturais da contemporaneidade, o que pode ser evidenciado na entrevista concedida por Getúlio dos Santos (2016).

Olha, eu acho que aos poucos, depois que aqui foi conhecido como comunidade quilombola, o Terno de Reis reviveu. Faz parte da nossa cultura né? A escola já colocou como atividade da escola. Na semana da consciência negra tem apresentação mirim. Eu mesmo acho isso importante.

Após ter sido reconhecido como local de quilombos, o terno de reis tomou uma dimensão mais consciente e, portanto, é manipulável de acordo com o querem dizer e visibilizar sobre o lugar.

\section{Breves considerações}

As festas religiosas em Nova Esperança apresentam traços de um conjunto etnográfico entre a sua história, a cultura e fé em seus santos de devoção, que interfere no cotidiano dos sujeitos que compõem o lugar. Assim, as misturas entre sagrado e profano resultaram em um alicerce da identidade deste território. De acordo com Carvalho (2007, p. 64) as manifestações culturais são representativas da voz social, "uma forma subjetiva que o grupo de pessoas encontra para expor seu interior, expressar o que pensam, o que desejam realizar ou modificar". 
Salientamos que o papel das mulheres de Nova Esperança nas manifestações religiosas e culturais é indispensável para a permanência das atividades, visto que os sujeitos que compõem um grupo são os atores que se reconhecem etnicamente e como tais compõem os caminhos do lugar, pois "os grupos étnicos são categorias adscritivas e de identificação, que são utilizadas pelos próprios atores e têm, portanto, a característica de organizar a interação entre os indivíduos” (BARTH, 2011, p.10-11). Nesse caso, é delas a missão de trazer as crianças para a "recriação cultural" através da dinâmica para o autoreconhecimento identitário e de sentimento de pertença.

A mulher atua como espécie de guardiã das tradições. Através de suas mãos, práticas culturais locais são protegidas. Elas são, portanto, fundantes para a manutenção da identidade quilombola.

E por fim, é através de suas festas religiosas e demonstração de fé e alegria que a comunidade quilombola de Nova Esperança homenageia seus ancestrais, revela saberes e fazeres na música, na dança, nas comidas e outros acontecimentos que tornam as pessoas pertencentes àquele lugar.

Neste contexto, fé, diversão e devoção se entrelaçam onde um não tem sentido sem que haja o outro. No âmbito da fé, há a mistura do catolicismo popular com as crenças provenientes de religiões de matrizes africanas, embora disfarçadamente.

\section{Referências Bibliográficas}

BARTH. Fredrik. O guru. O iniciador e outras variações antropológicas. - Fredrik Barh. Tradução de John Cunha Comerford. Rio de Janeiro: Contra C'P' Livraria. 2000.

BRASIL. Decreto $n^{o}$ 4.887, de 20 de novembro de 2003. Disponível em http://www.planalto.gov.br/ccivil_03/decreto/2003/d4887.htm . Acesso em: 23 de maio de 2017.

BOAS, Franz. Antropologia cultural. Org. Celso Castro. Rio de Janeiro: Jorge Zahar, 2004.

CARVALHO, Samanta V. C. B Rocha. "Manifestações Culturais" In: GADINI, Sérgio Luiz, WOLTOWICZ, Karina Janz (Orgs.) Noções Básicas de Folkcomunicação. Ponta Grossa (PR): UEPG, 2007.

CUCHE, Denys. O Conceito de Cultura nas Ciências Sociais. Tradução de Viviane Ribeiro. 2 ed. Bauru: EDUSC, 2002.

ELIADE, Mircea. O sagrado e o profano: a essência das religiões. Trad. Rogério Fernandes. $2^{\mathrm{a}}$ ed. São Paulo: Martins Fontes: 2008. 
LARAIA, Roque de Barros. Cultura: um conceito antropológico. 19 ed. Rio de Janeiro: Jorge Zahar, 2006.

PASSOS. Mauro. Religião, Festa e Sociedade. Revista Horizonte, Belo Horizonte, v. 9, n. 20, p.6-8, jan./mar. 2011.

QUINTÃO. Antônia Aparecida. "Irmandades negras: outro espaço de lutas e resistências." São Paulo. Annablume. 2002. In: ALVES. Vânia de Fátima Noronha. Os festejos do reinado de Nossa Senhora do Rosário em Belo Horizontel M.G: práticas simbólicas educativas. Universidade de São Paulo. 2008.

REIS. João José. Identidade e Diversidade étnicas nas Irmandades Negras no Tempo da Escravidão. Revista Tempo, Rio de Janeiro, vol. 2, nº 3, 1996.

HALBWACHS, Maurice. A memória coletiva. Edições Vértice. São Paulo, SP. Brasil. 1990.

HALL, Stuart. A identidade cultural na pós-modernidade. Tradução: Tomás Tadeu da Silva, Guacira Lopes Louro. 10. ed. , Rio de Janeiro: DP\&A, 2005.

HALL, S. Quem precisa da identidade?. In: HALL, S.; WOODWARD, K.; SILVA, T. S. (org.). Identidade e diferença: a perspectiva dos Estudos Culturais. Petrópolis: Vozes, 2008.

MENDONÇA, Antônio Gouvêa. O protestantismo no Brasil e suas encruzilhadas. Revista USP, São Paulo, n.67, p. 48-67, setembro/novembro 2005.

SANTANA, Marise de. ODEERE: formação docente, linguagens visuais e legado africano no sudoeste baiano. Vitória da Conquista: edições UESB, 2014.

WAGNER, Roy. A invenção da cultura. Trad. Marcela Coelho de Souza e Alexandre Morales. São Paulo: Cosac Naify, 2010.

Recebido em: 07/04/2020

Aceito em: 15/04/2020 